\title{
An Empirical Research on Female Income
}

\author{
Manxue Chen \\ School of Business, Northeast Normal University \\ Changchun, P.R. China, 130117 \\ chenmx839@nenu.edu.cn
}

\author{
Kangyin $\mathrm{Lu}$ \\ School of Business, Northeast Normal University \\ Changchun, P.R. China, 130117 \\ luky440@nenu.edu.cn
}

\begin{abstract}
Female income is one of the important factors that reflect the social status of women. By employing Nationwide Survey on the status of Chinese women, this paper analyzes female income and its influence factors through correlation analysis and multiple linear regression analysis. The results suggest that gender pay gap still remains; education significantly affects the income, but it is not the reason for causing the income gap; household registration system has an increasing impact upon gender pay gap; Technical and professional titles fail to contribute to the income of female workforce.
\end{abstract}

Keywords-female income; gender pay gap; mincer wage equation

\section{INTRODUCTION}

Equity theory believes that people's initiative correlates with their actual reward. The sense of fairness can influence the individual behavior, so it is attracting more attention. As traditional vulnerable groups, women require more attention. Since reform and opening, the economy of China is developing rapidly, but meanwhile, some issues such as the larger income gap between men and women, the increasing unemployment population of female, occupational gender segregation, the falling a sense of fairness and so on, become more and more prominent, and these issues seriously affect the social stability and sustainable development of economy for our country. Labor income is regarded as the embodiment of labor value and social justice, and the women's Income can comprehensively reflect the women's professional status and the social recognition of work value. Therefore, income equality is regarded as the core of gender equality. At present, the issue of female income has aroused general concern of domestic and foreign experts. Schultz (1953) believes that with the coming of knowledge economy and information era, the quality of human capital needs to be improved, and the human capital of female will influence their core competence, then influence the level of their income [1]. Oaxaca (1973) explores the effect of the gender difference on individual labor income in the US labor market [2]. Kabeer (2000) considers that gender has characters of economies and politics, so it will influence the other resources acquisition such as job assignment and wealth. And men are easy to obtain high-income jobs and management positions, but women can only get low-income jobs and temporary positions [3]. When Deng Dasong and Zhang Tianyu(2011) study the effect of education and work experience on income whether influenced by gender factor, they find that migrant workers' age, marriage, gender, unit character and the type of industries both have a significant effect on income, and the influence of gender variable on dependent variable mainly depends on its direct effect[4]. By using the method of the combination of theoretical analysis and empirical analysis, this paper attempts to study the factors of female income, and the key factors for causing gender gap in income.

\section{DATA VARIABLES AND MODELS}

This paper selected the second (in 2000) and third (in 2010) social status of Chinese women survey data as survey samples. This survey organized by the All-China Women's Federation (ACWF) and National Bureau of Statistics (NBS) is the data survey in the national scale, and its aim is to thoroughly and objectively reflect the status and the changes of Chinese women in a decade. It need to help government making scientific planning outline and policy measures for promoting women's development and gender equality, serving for scientific decision of women's work. This survey started from 1990. And up to the present, it has conducted 3 times, including 9 areas: health, education, economy, social security, etc.

Owing to the first survey belonged to test research data, and partial variables were different with later investigation, so this article mainly employed data2000 and data2010 for empirical analysis. Through data sieving and arrangement, 4508 samples are selected, which have 2123 samples in 2000(including 1187 women samples, 936 men samples) and have 2358 samples in 2010(including 1296 women, 1093 men).

This empirical model is extended from Mincer wage equation [5], as follows:

$$
\text { ln income }=\alpha+\beta_{i} X_{i}+\gamma_{j} W_{j}+\varepsilon
$$

Income is the natural logarithm of a specified number of the labor share. Xi represents demographic characteristics (sex, age, education). $\mathrm{Wj}$ represents work characteristics (condition, titles, types).

Table 1 shows the explained variable and the explanatory Variables. There are 9 explanatory variable, they can be divided into two groups according to type. One group is demographic characteristics, which includes gender, age group, education, hukou, marriage and health. And the other is work characteristics, which includes work, professional title, occupation, industry, start-age, and change-work. 
TABLE I VARIABLES OF THE EMPIRICAL RESEARCH

\begin{tabular}{|c|c|c|}
\hline Type & Name & Definition \\
\hline 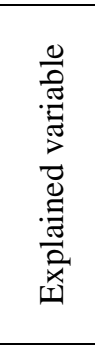 & In income & $\begin{array}{l}\text { The natural logarithm of } \\
\text { individual annual income. in } \\
\text { income (2000)=in labor } \\
\text { income; in income } \\
(2010)=\text { in (labor income + } \\
\text { pension and subsidy + } \\
\text { unemployment insurance, } \\
\text { living wage and allowance for } \\
\text { Three Rural) }\end{array}$ \\
\hline \multirow{14}{*}{ 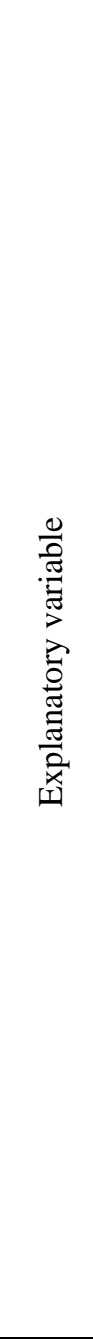 } & \multicolumn{2}{|c|}{ Demographic characteristics: } \\
\hline & Gender & Male $=1 ;$ Female $=0$ \\
\hline & Age group & $\begin{array}{c}1(18-29) ; 2(30-39) ; \\
3(40-49) ; 4(50-59) ; 5(60-64)\end{array}$ \\
\hline & Education & 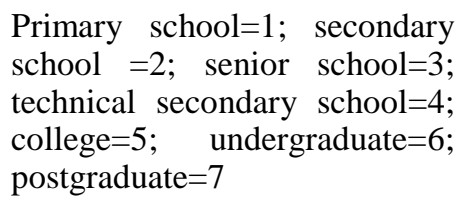 \\
\hline & Hukou & city $=1 ;$ rural $=0$ \\
\hline & Marriage & $\begin{array}{l}\text { Unmarried }=0 ; \text { Married }=1 ; \text { Divor } \\
\text { ced }=2 ; \text { Widowhood }=3\end{array}$ \\
\hline & Health & $\begin{array}{c}\text { Better }=4 ; \text { Good }=3 ; \text { Common }=2 ; \\
\text { Bad }=1 ; \text { Worse }=0\end{array}$ \\
\hline & \multicolumn{2}{|c|}{ Work characteristics: } \\
\hline & Work & Employed $=1 ;$ Unemployed $=0$ \\
\hline & $\begin{array}{l}\text { Professional } \\
\text { title }\end{array}$ & With titles $=1 ;$ Without titles $=0$ \\
\hline & Occupation & Classified by NBS \\
\hline & Industry & Classified by NBS \\
\hline & Start-age & Age when achieving first work \\
\hline & Change-work & $\begin{array}{l}\text { Times of changing work when } \\
\text { start work }\end{array}$ \\
\hline
\end{tabular}

\section{EMPIRICAL ANALYSIS}

\section{A. Related analysis of variables}

Firstly, this paper explored whether there was a significant correlation between the dependent variables and independent variables by Spearman analysis.

From the results of the correlation analysis in table 2, the correlation between marital status and income was not significant in the two-stage sample, and it is shown that the effect of marriage on income is not important in the modern society, so we should reject the marriage variable, when constructing a regression model. While the rest of the demographic characteristics variables and work characteristics variables are significantly related to the income, so all of them can enter the regression model.

In demographic characteristics, gender, education level, household registration and self-evaluated health were significantly positive related to income. Women's income is lower, well-educated can get well-paid job, rural people's income is lower than urban people. The healthy people can get the higher income. Age group is positively related to income in 2000 , but negatively related in 2000 , indicating that well-paid scale began to incline towards young people.

TABLE II SPEARMAN CORRELATION ANALYSIS

\begin{tabular}{|c|c|c|}
\hline & 2000 & 2010 \\
\hline \multicolumn{3}{|c|}{ Demographic characteristics: } \\
\hline Gender & $0.210^{* *}$ & $0.265 * *$ \\
\hline Age group & $0.051 *$ & $-0.124 * *$ \\
\hline Education & $0.354 * *$ & $0.290 * *$ \\
\hline Hukou & $0.351 * *$ & $0.140 * *$ \\
\hline Marriage & 0.043 & -0.020 \\
\hline Health & $0.053^{*}$ & $0.245 * *$ \\
\hline \multicolumn{3}{|l|}{ Work characteristics: } \\
\hline Work & $0.366^{* *}$ & $0.257 * *$ \\
\hline Professional title & $0.294 * *$ & $0.203 * *$ \\
\hline Occupation & $-0.178 * *$ & $-0.147 * *$ \\
\hline Industry & $0.387 * *$ & $0.245^{* *}$ \\
\hline Start-age & $0.170^{* *}$ & $0.168 * *$ \\
\hline Change-work & $0.169^{* *}$ & $0.096^{* *}$ \\
\hline
\end{tabular}

Note: $* * *$ respectively represent the critical value of Mackinnon significantly at the $5 \%$ and $1 \%$ level.

From the point of work characteristics, occupation types was significant negatively correlated with income, and which means that compared to a career in an ecological-economic and related people, head, skilled people and engaged in the management of people are more likely to get a higher income, which indicate that the people won the professional and technical titles can obtain the higher income; And start working age, we can understand for the relative length of education, will lead to higher income; work from in the number of times that a point of view, the greater the liquidity, the higher the income; Engaged in the industry, the more close to the simple physical labor, wage income is lower. 


\section{B. Regression analysis}

Based on the correlation analysis, this paper employed the model extended from Mincer wage equation to analyze on various factors influencing income by multiple regression analysis. The regression results are shown in table 3 :

TABLE III REGRESSION ANALYSIS OF INCOME IN SEX

\begin{tabular}{|c|c|c|c|c|c|c|}
\hline & \multicolumn{3}{|c|}{2000} & \multicolumn{3}{|c|}{2010} \\
\hline & All & Male & Female & All & Male & Female \\
\hline \multicolumn{7}{|c|}{ Demographic characteristics: } \\
\hline Gender & $0.125 * * *$ & - & - & $0.163 * * *$ & - & - \\
\hline Age group & 0.010 & 0.007 & 0.016 & $0.018^{* *}$ & -0.005 & $0.044 * * *$ \\
\hline Education & $0.053 * * *$ & $0.047 * * *$ & $0.060 * * *$ & $0.044 * * *$ & $0.042 * * *$ & $0.041 * * *$ \\
\hline Hukou & $0.085^{* * *}$ & $0.189 * * *$ & $0.135^{* * *}$ & $0.120 * * *$ & $0.065 * * *$ & $0.189 * * *$ \\
\hline Health & $0.037 * * *$ & $0.048 * * *$ & 0.020 & $0.051 * * *$ & $0.066 * * *$ & $0.037 * * *$ \\
\hline \multicolumn{7}{|c|}{ Work characteristics: } \\
\hline Work & $0.039 * * *$ & $-0.075^{* *}$ & $-0.141 * * *$ & $-0.093 * * *$ & $-0.062 * * *$ & $-0.121 * * *$ \\
\hline Professional title & 0.004 & 0.011 & 0.001 & $0.067 * *$ & $0.069 * *$ & 0.065 \\
\hline Occupation & -0.005 & -0.004 & -0.003 & $-0.023 * * *$ & -0.015 & $-0.042 * * *$ \\
\hline Industry & 0.002 & $0.008 * *$ & 0.003 & -0.002 & 0.002 & $-0.006 * *$ \\
\hline Start-age & $-0.003 *$ & -0.002 & -0.003 & 0.001 & 0.001 & $0.004 * *$ \\
\hline Change-work & 0.002 & 0.003 & 0.002 & $-0.001 * *$ & 0.002 & $-0.002 * * *$ \\
\hline$\alpha$ & $3.753 * * *$ & $3.879 * * *$ & $3.604 * * *$ & $4.563 * * *$ & $4.348 * * *$ & $4.355^{* * *}$ \\
\hline R2 & 25.6 & 22.5 & 20.9 & 27.1 & 24.3 & 26.6 \\
\hline $\mathrm{F}$ & $40.5^{* * *}$ & $22.6^{* * *}$ & $16.4 * * *$ & $63.8^{* * *}$ & $24.6^{* * *}$ & $32.4 * * *$ \\
\hline
\end{tabular}

Note: *,***** respectively represent the critical value of Mackinnon significantly at the $10 \%, 5 \%$ and $1 \%$ level.

First, in the results of the whole sample regression, the gender income return both was significantly positive in two installments, and the regression coefficient rise from 0.125 in the second phase (2000) to the 0.163 in the third period (2010), which shows that men are more likely than women to obtain high income, and the gender pay gap is constantly expanding.

Second, for the age factor, from the results of whole sample regression, in 2000, the influences of age on income didn't pass the significance test, and in 2010, the influences is also weak. In 2010, the results of gender sample regression showed that age had no significant effect on men's income, but can significantly effect on the income of women. Age increased every year, the logarithmic of women's annual income increased by $4.4 \%$.
Third, the effect of education on income was very significant. From the perspective of the results of gender sample regression, there are no significantly difference for the influence of income on both men and women. This may be due to the popularization of compulsory education, which makes the growing numbers of the education, both men and women can quickly acquire knowledge, the proportion of the education effect on income on the gender gradually is into balance.

Fourth, from the point of the household registration, regression results show that after the change of 10 years, the household registration has more important effect on the income. From the perspective of the results of gender sample regression, in 2010, the situation of women's income has more influences from the household factors than men. In 2000, household registration both have the effect on the income of 
men and women , and the coefficient of women is 0.135 , but in 2010 is 0.189 , which shows that after the change of 10 years, the influence of the household registration on women's income has intensified.

Fifth, during ten years, the degree of impact of the health on income has increased from the regression coefficient, the health income returns of men is higher than women, suggesting that compared with women, the health is more easy to affect the income of men.

Sixth, in 2000, the influence of professional and technical titles on income was not significant, but in 2010, it was significant, that illustrate the impact of professional and technical titles on the income has increased in ten years, and Jilin province is gradually beginning to shift demand for technology, and the skilled people can get higher income. From the results of gender sample regression, the effect of professional and technical titles on income can only embody in male labors. The regression coefficient of other variables, including occupation type, age, industry type, the age of the beginning to work and the frequency of changing job, basically were significant only in the third stage female samples, and the coefficient value is very small, which means that these three factors has little impact for gender income. Working state variables in the regression results show the opposite trend in two phase, these differences were produced by the different definition of the variables.

\section{CONCLUSION}

This paper employed the second and third social status of Chinese women survey data in 2000 and 2010, using the correlation analysis and multivariate linear regression analysis, through two phase of the data of annual comparison and gender comparison, on the one hand, analysis of various factors affecting women's income and its annual change trend of influence, on the other hand, studies the influence factors of gender pay gap. The results showed that, demographic characteristic and work characteristic significantly influence on women's income; the gender pay gap between men and women exist and present expansion trend; the effect of human capital factor represented by education on the income is significant, but its impact on the gender pay gap is not significant; the effect of household factor on women's income and the gender pay gap are increasing; the influence of professional and technical titles on women's income is not significant. The government should make efforts to narrow the gap between urban and rural, and develop non-agricultural industries, make rural women liberate from the land, so as to realize the diversified channels of increasing of women income Meanwhile, we should improve the employment rate of the female, changing the structure of employment. And the government should regulate wage management system, and constantly change the condition of low wages and get different pay of female.

\section{REFERENCES}

[1] Schultz T W. The economic organization of agriculture[M]. New York: McGraw-Hill, 1953.

[2] Oaxaca R. Male-female wage differentials in urban labor markets[J]. International economic review, 1973(19): 693-709.

[3] Kabeer N. Social exclusion, poverty and discrimination towards an analytical framework[J]. IDS bulletin, 2000, 31(4): 83-97.

[4] Dasong Deng, Tianyu Zhang.A Test on Gender-bias of the Migrant Farmers' Human Capital on the Relations of Labor Income[J]. MANAGEMENT REVIEW, 2011(4):73-79.(in Chinese)

[5] Mincer J. Schooling, Experience, and Earnings[M]// Schooling, experience, and earnings. National Bureau of Economic Research; distributed by Columbia University Press, 1974:218-223.. 